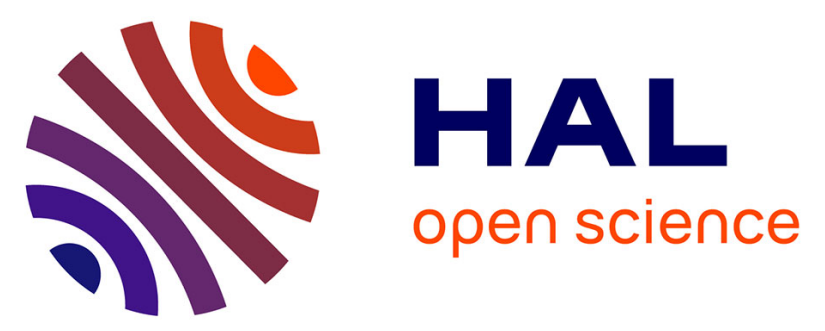

\title{
Abatement of 3-methylbutanal and trimethylamine with combined plasma and photocatalysis in a continuous planar reactor
}

Aymen Amine Assadi, Jordi Palau, Abdelkrim Bouzaza, Josep Penya-Roja, Vicente Martinez-Soriac, Dominique Wolbert

\section{To cite this version:}

Aymen Amine Assadi, Jordi Palau, Abdelkrim Bouzaza, Josep Penya-Roja, Vicente Martinez-Soriac, et al.. Abatement of 3-methylbutanal and trimethylamine with combined plasma and photocatalysis in a continuous planar reactor. Journal of Photochemistry and Photobiology A: Chemistry, 2014, 282, pp.1-8. 10.1016/j.jphotochem.2014.03.001 . hal-00981617

\section{HAL Id: hal-00981617 https://hal.science/hal-00981617}

Submitted on 18 Jul 2014

HAL is a multi-disciplinary open access archive for the deposit and dissemination of scientific research documents, whether they are published or not. The documents may come from teaching and research institutions in France or abroad, or from public or private research centers.
L'archive ouverte pluridisciplinaire $\mathbf{H A L}$, est destinée au dépôt et à la diffusion de documents scientifiques de niveau recherche, publiés ou non, émanant des établissements d'enseignement et de recherche français ou étrangers, des laboratoires publics ou privés. 


\title{
Abatement of 3-methylbutanal and trimethylamine with combined plasma and photocatalysisin a continuous planar reactor
}

\author{
ASSADI Aymen Amine ${ }^{\text {a.b }}$, PALAU Jordi ${ }^{c}$, BOUZAZA Abdelkrim a,b*, PENYA-ROJAJosep M $^{\mathrm{c}}$, \\ MARTINEZ-SORIAVicente ${ }^{c}$, WOLBERT Dominique ${ }^{\mathrm{a}, \mathrm{b}}$ \\ ${ }^{\text {a }}$ Laboratoire Sciences Chimiques de Rennes - équipe Chimie et Ingénierie des Procédés, UMR 6226 \\ CNRS, ENSCR, 11 allée de Beaulieu, 35700 Rennes, France. \\ ${ }^{\mathrm{b}}$ Université Européenne de Bretagne. \\ ${ }^{\mathrm{C}}$ Department of Chemical Engineering, University of Valencia, Dr. Moliner 50, 46100 Burjassot, \\ Spain \\ * Corresponding author. Tel.: +33 2 23238056; fax: +33 223238120. \\ E-mail address: Abdelkrim.bouzaza@ensc-rennes.fr (A. BOUZAZA).
}

\begin{abstract}
This paper deals with the 3-methylbutanal $\left(\left(\mathrm{CH}_{3}\right)_{2} \mathrm{CHCH}_{2} \mathrm{COH}\right)$ removal with the help of a nonthermal surface plasma discharge coupled with photocatalysis. The capability of this process for gas treatmentwas studied. A planar reactor system was developed in order to perform the effect of adding photocatalytic materialin plasma surfacedischarge barrier dielectric (SDBD) zone on (i) 3-methylbutanalremoval, (ii) selectivity of $\mathrm{CO}_{2}$ and $\mathrm{CO}$, (iii) byproducts formation such ozone formation.

It was found that the influence of the UV light generated by SDBD reactor was very low. The activation of the photocatalyst media could be negligible. Whereas, the introduction of external UV light to the process improves significantly the removal efficiency of 3methylbutanal(3MBA) and the mineralization. A synergetic effect was observedby combining plasma SDBD and photocatalysis from all experiments and with other pollutant such as

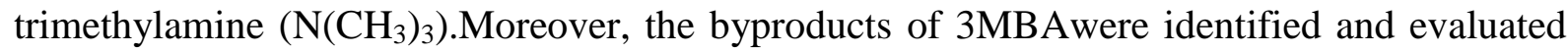
with plasma SDBD, photocatalysis and plasma SDBD/photocatalysis combination.
\end{abstract}

\section{Keywords:}

Synergetic effect; planar reactor; Plasma SDBD/photocatalysis process; VOC removal

\section{Introduction}


The continual release of toxic gases into the atmosphere from variety of sources (due to industrial discharges, transports, use of paints, domestic activities, etc.) has resulted in the gradual degradation of the environment [1]. This consequence, in turn, has motivated investigations into new methods of reducing and, if possible, preventing these harmful emissions [2]. An increasing awareness of these emissions has resulted in legislation requiring stringent enforcement of new regulations having the goal of improving the quality of the environment [2]. As a result, many conventional techniques were proposed to remove VOCs such as, ozone oxidation [4], incineration[5], combustion [6], adsorption [7], absorption and photocatalysis $[3,8,14,39,40,42-44]$.

Photocatalysis is an heterogeneous process between a solid phase (catalyst) containing a semiconductor usually titanium dioxide $\left(\mathrm{TiO}_{2}\right)$ and the gas phase $[9,40,42,43]$. The catalyst is activated by photons provided by an ultra violet (UV) radiation (sunlight or UV lamps) [10$12,14,44]$. This technique has proven its ability to mineralize a large number of VOCs with low energy consumption $[9,13]$. Thus it appears to be a promising process for remediation of air polluted by VOCs. Heterogeneous photocatalysis using $\mathrm{TiO}_{2}$ has several advantages: (i) the catalyst is cheap, (ii) it operates at ambient temperature, (iii) the byproducts are usually $\mathrm{CO}_{2}$ and $\mathrm{H}_{2} \mathrm{O}$, (iv) no other chemical reagent is needed.

Recently, the Nonthermal plasma (NTP) has been investigated, first time, by many researchers for various applications such as removal of pollutants. The main advantage of these non equilibrium plasmas consists in the ability to generate high-energy electrons, while keeping the background gas close to room temperature[15]. Thus, a highly reactive environment is created without spending energy on gas heating as in thermal processes [15, 16]. The energetic electrons excite, dissociate and ionize the gas molecules producing chemically active species[17].

In recent years, plasma dielectric barrier discharge (DBD) has been investigated for the abatement of volatile organic compounds including methanol [40], benzene [18], dimethylamine [19], toluene [20, 21] and hydrogen sulfide [22].

The use of a catalyst in the plasma zone was reported to improve the efficiency in VOC removal and $\mathrm{CO}_{2}$ formation $[30,32,37,40]$. The goal of this study was to try to combine the advantages of photocatalysis and NTP by combining the two technologies in the same reactor which should be able to treat larger flowrate than the laboratory reactors usually used. Moreover, we can expect to observe a synergy effect by combining volumic plasma with photocatalyst in a small reactor at flowrate equal to $200 \mathrm{~mL} \cdot \mathrm{min}^{-1}[24,26]$. 
A coupled system of surfacic plasma/photocatalysis in pilot reactor is established in the present work to study the effect of adding UV external onthe pollutant degradation and byproducts formation. 3-methylbutanal (3MBA) and trimethylamine (TMA)were chosen as target pollutantssince these compoundswere main molecules detected in the exhaust gases from animal quartering centers.

\section{Experimental details}

\subsection{Reactor design and setup details}

The planar reactor consists of a rectangular cross section $(135 \mathrm{~mm} \times 135 \mathrm{~mm})$ and is $1 \mathrm{~m}$ length. It is made of polymethyl methacrylate (PMMA) material. Two plates, 4mm thickness, are arranged parallelto the length ofthe reactor and permit to hold up the catalyst media and the two electrodes. The distance between the two plates, which is also the air gap, can be modified. The planar photocatalytic reactor was equipped with eight UV lamps in order to ensure a good radiation distribution (Fig. 1). The length of the irradiated zone is $0.8 \mathrm{~m}$. The photocatalytic support surface is equal to $0.19 \mathrm{~m}^{2}$. The used fluorescent UV lamp (Philips under reference PL-S 9W/10/4P, 0.012m bulb diameter, $0.135 \mathrm{~m}$ bulb length) had a major wavelength peak emission at $355 \mathrm{~nm}$. The centerlines of the lamps were separated by a distance of $0.01 \mathrm{~m}$.

The design of this reactor (Figure.2) was the subject of a Patent Application (BFF 11L1040/GB) [27].

The nonthermal plasma, of surface dielectric barrier type, is generated by a $2 \mathrm{~mm}$ thickness grid with wire electrodes shaped as a rectangle. The distance between two wire electrodes was $20 \mathrm{~mm}$. The outer electrode, connected to the ground, is a $1 \mathrm{~mm}$ thick and $80 \mathrm{~cm}$ length copper foil. The electrodes were attached around the glass plate which its thickness $(4 \mathrm{~mm})$ corresponded to the distance between them. The applied high voltage is about $30 \mathrm{kV} / 40 \mathrm{~mA}$ and is a sine waveform. It was delivered by a TREK_30kV high voltage amplifier coupled with a generator BFi OPTILAS.

\section{Figure 1: sectional drawing (a) and Schema (b) of plasma SDBD coupled with} photocatalysis in planar reactor. 
The applied voltage to the plasma SDBD was measured with a 1000:1 high voltage probe (North Star SN_1704010). The NTP was obtained by submitting the electrodes to a sinusoidal electric high voltage ranging from 0 to $30 \mathrm{kV}$ at a $50 \mathrm{~Hz}$ frequency. A 2,5 $\mathrm{nF}$ capacitance $\left(\mathrm{C}_{\mathrm{m}}\right)$ was positioned between the outer electrode and the ground connection in order to collect the charges transferred through the reactor. The applied voltage $\left(U_{a}\right)$ and the high capacitance voltage $\left(\mathrm{U}_{\mathrm{m}}\right)$ were measured by LeCroy high voltage probes and recorded by a digital oscilloscope (Lecroy Wave Surfer $24 \mathrm{Xs}, 200 \mathrm{MHz}$ ). A schematic illustration of the plasma SDBD setup is shown in Fig.2.

(a)

Fig 2: (a) General scheme for coupling plasma SDBD and photocatalysis, (b) photographs of plasma SDBD in planar reactor.

\subsection{Polluted flow generation}

A centrifugal compressor is used with ambient air. The flow rate is controlled by a flow meter (Bronkhorst In-Flow). 3MBA(>99.7\%, Sigma-Aldrich, Switzerland) and TMA(50wt. \% solution in water, Sigma-Aldrich, Switzerland) were used.Each pollutant iscontinuouslyinjected by means of a syringe/syringe driver system (Kd Scientific Model 100) through a septum into the gas stream and a heating system covering the injection zone sets the gas temperature and facilitates the VOC vaporization ahead of the static mixer (Fig.3).

Figure 3: Schematic view of the experimental setup

\subsection{Apparatus and Analysis}

For the analysis, a FISONS Gas chromatograph coupled with a flame ionization detector (GCFID) is used. 3MBA and byproducts separation are performed by a Chrompact FFAP-CB column ( $25 \mathrm{~m}$ of length $0.32 \mathrm{~mm}$ of external diameter $0.32 \mathrm{~mm}$ ), which is specially adapted for volatile fatty acids. Nitrogen gas constitutes the mobile phase. The identification of byproducts is done by Gas Chromatograph-Mass spectrometer (GC-MS) (Thermo Scientific) equipped with an infrared (IR) detector. Under these conditions, the detectionlimit of 3MBA and formed byproducts was 0.02ppmv.All injections are performed manually and repeated three times with a syringe of $500 \mu 1$. Analysis conditions are as follows (Table 1). 
136

137

138

139

140

141

142

143

144

145

146

147

161

A standard iodometric titration method was used to estimate the formation of the downstream ozone.Thus, at the outlet of the plasma reactor a constant flow rate of $200 \mathrm{~L} / \mathrm{h}$ was bubbled on iodine solution. The $\mathrm{CO}_{2}$ has been analyzed by a Fourier Transform Infrared (FTIR) spectrophotometer brand Environnement SA (Cosma Beryl reference 100). CO concentrations were measured by CO ZRE gas analyzer. Temperature and relative humidity were measured with a TESTO 445 probe.

\subsection{Photocatalytic material}

The used materialis a coated Glass Fiber Tissue (GFT) with $6.5 \mathrm{~g} / \mathrm{m}^{2}$ of colloidal silica to ensure the fixation of $6.5 \mathrm{~g} / \mathrm{m}^{2}$ of P25-Degussa titanium dioxide nanoparticles. It is supplied by Ahlstrom Research and Services. P25-Degussa nanoparticles were made of two titanium dioxide allotropic forms, $80 \%$ is anatase, $20 \%$ is rutile. The coating process consists of an impregnation of glass fibers by $\mathrm{SiO}_{2}$ and $\mathrm{TiO}_{2}$ nanoparticles suspension in pure water using Ahlstrom industrial size-press. Specific surface area was measured according to BET method and was equal to $20.6 \mathrm{~m}^{2} \mathrm{~g}^{-1}$. Preparation process is precisely described in the study of Enriquez and co-workers [14] and Ahlstrom Patent [28].

\section{Results and Discussion}

The average temperature was equal to $20{ }^{\circ} \mathrm{C}$. It should be noted that, whether the UV lamp could potentially heat up the air, themeasured outlet temperature of the gas never exceeds the above-mentioned value. This is due to the nature of the open continuous reactor where the airflow evacuates the heat.

\subsection{Removal of 3-methylbutanal}

The VOC Removal Efficiency (RE) is defined as:

$R E(\%)=\frac{C_{\text {in }}-C_{\text {out }}}{C_{\text {in }}} \times 100 \%$

162 Where $\mathrm{C}_{\text {in }}$ and $\mathrm{C}_{\text {out }}$ are the inlet and outlet concentration of 3MBA (mg. $\mathrm{m}^{-3}$ ) respectively. 
Moreover we use the Lissajous plot method (Manley, 1943) for calculating mathematically the power input (P) (eq.2).

$$
\mathrm{P}(\mathrm{W})=\mathrm{E}(\mathrm{J}) \mathrm{xF}(\mathrm{Hz})
$$

Where $\mathrm{P}$ is the input power $(\mathrm{W}), \mathrm{E}$ is the injected energy $(\mathrm{J})$ and $\mathrm{F}$ is the frequency $(\mathrm{Hz})$. The value of input power is varied by changing the applied voltage (Ua). In fact, the injected energy (E) per cycle dissipated in the DBD reactor is equal to the area of Lissajous curve (Fig.2).A Lissajous curve was obtained by plotting the charges transferred by the plasma versus thevoltage applied to the reactor, as shown in figure 2.

The quantity of charges $\mathrm{Q}(\mu \mathrm{C})$ transferred by the dischargewas measured by multiplying the capacitance $\mathrm{C}_{\mathrm{m}}(\mathrm{nF})$ by the applied voltage $\mathrm{Ua}(\mathrm{kV})$ in the plasma SDBD reactor [45].

In the case of fig.2, the discharge power was estimated to be $6 \mathrm{~W}$.

After the specific energy (SE) is then calculated as:

$\mathrm{SE}(\mathrm{J} / \mathrm{L})=\mathrm{P}(\mathrm{W}) /\left[1000 * \mathrm{Q}\left(\mathrm{m}^{3} / \mathrm{h}\right) / 3600\right]$

Where SE was the specific energy $(\mathrm{J} / \mathrm{L}), \mathrm{Q}$ was the flowrate $\left(\mathrm{m}^{3} / \mathrm{h}\right)$.

\section{Figure 4: Lissajous curve obtained at $50 \mathrm{~Hz}$.}

\section{Results and discussion}

The main target of this work was to study the removal of 3MBA by plasma coupled with $\mathrm{TiO}_{2}$ without external UV in order to investigate the effect of UV light from the SDBD reactor in $\mathrm{TiO}_{2}$ activation.

The effects of several parameters, such as specific energy (SE), residence time in the reactor and inlet concentration on the contaminant removals were investigated.

The domain of gas flowrate, inlet concentration tested, UV intensity, and the applied voltage of plasma SDBD were summarized in Table 2.

Table 2: Parameters of plasma $\mathrm{DBD}^{\mathrm{TiO}} \mathrm{Ti}_{2} / \mathrm{UV}$ reactor

\subsection{Influence of UV generated by plasma on $\mathrm{TiO}_{2}$}

\subsubsection{On removal of 3-methylbutanal}


During the present study, concentration of 3MBAwas kept constant $\left(50 \mathrm{mg} \cdot \mathrm{m}^{-3}\right)$ in order to understand the influence of SE on the performance of the reactor. Moreover, the applied voltage was varied between 12 and $29 \mathrm{kV}$ that corresponds to $\mathrm{SE}$ of 5 and $16 \mathrm{~J} . \mathrm{L}^{-1}$, respectively. As seen from Fig. 5, with the two processes (plasma only and plasma with $\mathrm{TiO}_{2}$ without external UV), removal of 3MBAincreases with increasing the SE.In fact, the radicals and the excited species which were produced by the energetic electrons in the discharge phase could efficiently oxidize 3MBAand accordingly improved the RE of 3MBA. This result is in agreement with works on plasma SDBD removal of methanol [40], acetylene [23] andtoluene $[20,21]$.

On the other hand, Fig.5 shows that the RE of 3MBAwas not enhanced in presence of photocatalyst without external UV. So, the UV light from the plasma SDBDwas very weak to activate the $\mathrm{TiO}_{2}$. Its contribution to the removal of 3MBAin plasma SDBD/photocatalysis combination reactor could be ignored. Similar results have been reported in the literature for some VOCs $[23,24]$.

\section{Figure 5: Dependence of RE on SE in situ in different plasma systems without external}

$$
\mathrm{UV}\left([3 \mathrm{MBA}]=\mathbf{5 0} \mathrm{mg} \mathrm{m}^{-3}, \mathrm{Q}=10 \mathrm{~m}^{3} \mathrm{~h}^{-1}, \mathrm{~T}=20{ }^{\circ} \mathrm{C}, \mathrm{RH}=\mathbf{5 0 \%}\right) \text {. }
$$

\subsubsection{On selectivities of $\mathrm{CO}$ and $\mathrm{CO}_{2}$}

The $\mathrm{CO}_{2}$ overall selectivity ( $\mathrm{CO}$ overall selectivity can be also defined) may be a useful parameter to assess the performance of the plasma SDBD towards 3MBAremoval. It allows estimating the mineralization rate i.e. the ultimate reaction step, of each process of oxidation.

The $\mathrm{CO}_{\mathrm{x}}$ selectivity is expressed as follow (eq. 4):

$$
\left\{\mathrm{CO}_{\mathrm{x}} \text { 's overall selectivity }(\%)\right\}=\frac{\left[\mathrm{CO}_{\mathrm{x}}\right]^{\text {out }}-\left[\mathrm{CO}_{\mathrm{x}}\right]^{\text {in }}}{5 \times[3 \mathrm{MBA}]^{\text {in }} \times\{\% \mathrm{RE}\}} \times 10^{4}
$$

where $\mathrm{x}=1$ for $\mathrm{CO}$ and $\mathrm{x}=2$ for $\mathrm{CO}_{2} \cdot\left[\mathrm{CO}_{\mathrm{x}}\right]^{\text {in }}$ and $\left[\mathrm{CO}_{\mathrm{x}}\right]^{\text {out }}$ werethe inlet and outlet concentration of carbon mono/dioxide respectively (ppmv). [3MBA] ${ }^{\text {in }}$ was the inlet concentration of 3MBA (ppmv). The number 5 was the stoechiometric coefficient of the removal reaction. 

without external UV: empty symbol = selectivity of $\mathrm{CO}_{2}$ and full symbol $=$ selectivity of $\mathrm{CO}\left([3 \mathrm{MBA}]=50 \mathrm{mgm}^{-3}, \mathrm{Q}=10 \mathrm{~m}^{3} \mathrm{~h}^{-1}, \mathrm{~T}=20{ }^{\circ} \mathrm{C}, \mathrm{RH}=\mathbf{5 0 \%}\right)$.

Fig. 6.ashows the selectivity of $\mathrm{CO}_{\mathrm{x}}\left(\mathrm{CO}\right.$ and $\left.\mathrm{CO}_{2}\right)$. As seen, the selectivity of $\mathrm{CO}_{\mathrm{x}}$ was bad and never close to $100 \%$. In fact, the selectivity to $\mathrm{CO}_{2}$ was around $19 \%$ at $16 \mathrm{~J} . \mathrm{L}^{-1}$. Moreover, we note that the increase of SE leads to an increase of overall selectivities. This is due to more electrons and reactive species (such as ${ }^{\circ} \mathrm{O}$ and ${ }^{\circ} \mathrm{OH}$ ) which were formed when the SE increased and then much molecules of $3 \mathrm{MBAwere}$ oxidized into $\mathrm{CO}_{2}$ and $\mathrm{CO}[26,40,46]$. In fact an increase in SE from 5, 2 to $16 \mathrm{~J}^{-\mathrm{L}^{-1}}$ leads to $\mathrm{CO}$ and $\mathrm{CO}_{2}$ overall selectivity increased from 3 to $12 \%$ and from 9 to $19 \%$, respectively. These results are in agreement with works on removalof methanol [40], acetaldehyde [30] and acetylene [26, 31].

We can also note that the presence of photocatalyst on the plasma zone, does lead to more mineralization.

The others byproducts in the exit of reactor were identified and evaluated.To evaluate the validity of the analysis method i.e. to be sure that the majority of byproducts were detected, mass carbon balance was estimated (fig.6.b).

In fact, mass carbon balance $\mathrm{CB}(\%)$ was calculated from the sum of acetone $\left(\mathrm{CH}_{3} \mathrm{COCH}_{3}\right)$, acetic acid $\left(\mathrm{CH}_{3} \mathrm{COOH}\right), \mathrm{CO}_{2}$ and $\mathrm{CO}$ as follows:

$$
\mathrm{CB}(\%)=\frac{\left[\mathrm{CH}_{3} \mathrm{COOH}\right]+\left[\mathrm{CH}_{3} \mathrm{COCH}_{3}\right]+\left[\mathrm{CO}_{2}\right]+[\mathrm{CO}]}{5 \times[3 \mathrm{MBA}]^{\text {in }} \times\{\% \text { IRE }\}_{\text {Isov }}} \times 100 \%
$$

where $\left[\mathrm{CH}_{3} \mathrm{COOH}\right],\left[\mathrm{CH}_{3} \mathrm{COCH}_{3}\right],[\mathrm{CO}]$ and $\left[\mathrm{CO}_{2}\right]$ were respectively the concentration of acetic acid, acetone, carbon monoxide and carbon dioxide (ppmv). Figure 6.b shows that with these processes the mass carbon balance was achieved. This means that the majority of organic byproducts are detected. Moreover, we obtained the same byproducts using two processes without external UV.

$$
\begin{aligned}
& \text { Fig.6.b. Variation of mass balances and byproducts of } 3 \mathrm{MBAwith} \text { residence time using } \\
& \text { plasma alone and plasma with } \mathrm{TiO}_{2}\left([3 \mathrm{MBA}]=50 \mathrm{mg} \mathrm{m}^{-3}, \mathrm{Q}=10 \mathrm{~m}^{3} \mathrm{~h}^{-1}, \mathrm{~T}=20{ }^{\circ} \mathrm{C}, \mathrm{RH}=\right. \\
& 50 \%)
\end{aligned}
$$




\subsubsection{On the ozone formation}

Ozone is an inevitable byproduct in a NTP. Atomics oxygenwere generated by $\mathrm{O}_{2}$ dissociation due to impact with high energy electrons (reaction 1).

$$
\mathrm{e}^{-}+\mathrm{O}_{2} \rightarrow \mathrm{e}^{-}+{ }^{\circ} \mathrm{O}+{ }^{\circ} \mathrm{O}
$$

Atomics oxygen are a strong oxidizer, but its stability is very limited. Due to fast recombination processes, the lifetime is only a few microseconds at atmospheric pressure [4, $16,38,39]$

Atomic oxygen reacts successively with $\mathrm{O}_{2}$ in three-body collisions, forming ozone by the following reaction:

$\cdot \mathrm{O}+\mathrm{O}_{2}+\mathrm{M} \rightarrow \mathrm{O}_{3}+\mathrm{M}$

where $\mathrm{M}$ can be either molecular oxygen or molecular nitrogen [4].

As seen from Fig 7, when the SE increases, the quantity of ozone increases as wall. That could be explained by the fact that more electrons and reactive species (such as ${ }^{\circ} \mathrm{O}$ ) were formed and then leads to ozone production (reactions $1 \& 2$ ) [16, 38, 39].

\section{Figure 7: Dependence of the ozone formation on $\mathrm{SE}$ on in situ under different plasma} systems without external UV ([3MBA] $\left.=50 \mathrm{mg} \mathrm{m}^{-3}, Q=10 \mathrm{~m}^{3} \mathrm{~h}^{-1}, \mathrm{~T}=20{ }^{\circ} \mathrm{C}, \mathbf{R H}=\mathbf{5 0 \%}\right)$

Moreover, it is interesting to note that the presence of photocatalyst without external UV surface enhances the quantity of ozone in the outlet flow. Thus, this experiment illustrates that the active species generated $\left({ }^{\circ} \mathrm{O}\right)$ by plasma are able to react with other species like fibers of $\mathrm{TiO}_{2}$ than to recombine with oxygen molecules for forming ozone (reaction 2). This result is similar to the work of Allegraud [32].

\subsection{Combination of plasma-photocatalysis with external UV}

The UV light generated by plasma SDBD is very weak to activate the $\mathrm{TiO}_{2}$. Its contribution to the 3MBA removal by plasma SDBD/photocatalysis combination reactor could be ignored.Thus, we introduced eight external UV light into the planar reactor to activate the photocatalyst media. Moreover,3MBA removal experiments were carried out under three 
configurations: photocatalysis $\left(\mathrm{TiO}_{2}+\mathrm{UV}\right)$, plasma and plasma $\mathrm{SDBD} /$ photocatalysis coupling (Plasma SDBD/TiO $2+\mathrm{UV}$ ). The removal efficiency, mineralization and by-products formation are determined.

It is important to note that without photocatalystmedia, 3MBA removal is not affected by UV radiations.

\subsubsection{On the removal efficiency}

On Figure 8, the variation of 3MBAremoval efficiency, by coupling process, as a function of the sum of removal efficiency due to plasma and photocatalysis is represented.

We can see that 3MBA removal by coupling plasma and photocatalysis was about 5 to $15 \%$ higher than the sum of the conversions recorded, under the same conditions, for plasma and photocatalysis alone.

For example, when $[3 \mathrm{MBA}]=50 \mathrm{mgm}^{-3}$ and $\mathrm{Q}=4 \mathrm{~m}^{3} \cdot \mathrm{h}^{-1}$, by photocatalysis alone, the removal efficiency of 3MBAwas around $25 \%$. When NTP alone ( $\left.\mathrm{SE}=13.7 \mathrm{~J} . \mathrm{L}^{-1}\right)$ was used, the 3MBA removal reaches to $48 \%$. By coupling plasma SDBD and photocatalysis, the 3MBA removal increased to $83 \%$ ( $10 \%$ higher than the contribution of each process).

This synergetic effect was observed under various experimental conditions (Fig.8)

This synergy may be assigned to:

- The contribution of reactive species, formed by plasma SDBD, in photocatalytic mechanisms [23, 37, 40].

- The desorption of by-products attached at $\mathrm{TiO}_{2}$ surface by plasma. This leads to renewal of catalytic surface and so improvesconversion and mineralization processes $[24$, 36]

Figure.8: 3MBAremoval efficiency by coupling process vs the sum of removal efficiency of plasma and photocatalysis at different residence time, inlet concentration and specific energy in planar reactor $\left(\mathrm{T}=20{ }^{\circ} \mathrm{C}, \mathbf{R H}=50 \%, \mathrm{I}=20 \mathrm{~W} \cdot \mathrm{m}^{-2}\right)$.

So as to better understand the presence of synergetic effect with plasma and photocatalysis, others experiments with TMAwere carried out. 
Figure 9 shows the variation of the TMAremoval with flowrate using the three configurations at $\mathrm{SE}=13 \mathrm{~J} . \mathrm{L}^{-1}$.

Figure 9: TMAremoval with flow rate for the different tested configurations $\left(\mathrm{SE}=13 \mathrm{~J}^{-} \mathrm{L}^{-}\right.$ $\left.{ }^{1},[\mathrm{TMA}]=145 \mathrm{mg} / \mathrm{m}^{3}, \mathrm{RH}=50 \%, \mathrm{~T}=20^{\circ} \mathrm{C}\right)$.

On the other hand, figure 9 illustrates the results for TMAremoval for the photocatalysis alone (UV), plasma SDBD alone (without $\mathrm{TiO}_{2}$ ) and for the coupling of plasma SDBD and photocatalysis. By photocatalysis alone (irradiation of $\mathrm{TiO}_{2}$ by external UV light), $24 \%$ of the TMA was removed. When plasma SDBD was used alone and at $\mathrm{Q}=4 \mathrm{~m}^{3} \cdot \mathrm{h}^{-1}$, the TMA removal reaches to $36 \%$ without photocatalyst.

By coupling plasma SDBD and photocatalysis, the TMAremoval increased to $74 \%$. Thus, the TMA removal by coupling plasma SDBD and photocatalysis was $14 \%$ higher than the sum of the removals recorded at the same conditions for plasma SDBD alone and photocatalysis alone. With this pollutant, we note that the synergistic effect washigherthan that with 3MBA. Thus, whatever the pollutant was used, experimental results when plasma SDBD and photocatalysis were combined show a better efficiency in removal than the simple addition of the two processes, revealing then a synergy effect which it appears for all the values of tested flowrate.

\subsubsection{On the selectivity of $\mathrm{CO}_{2}$}

The CO selectivity can be considered as negligible for plasma and plasma SDBD /photocatalysis coupling processes.

We note that, with photocatalysis alone the final concentration of $\mathrm{CO}$ was lower than the detection limits of CO ZRE analyzer $(<0.05 \mathrm{ppmv})$. This result is in agreement with works on photocatalytic degradation of fatty acids [33], cyclohexane [34] and trichloroethylene (TCE) [9]. On other hand, $\mathrm{CO}$ detection could be obviously affected by the residence time under otherwise identical conditions. In fact, with decomposition of gas-phase dimethyl methylphosphonate [46], photocatalysis alone can produce a very low amount of CO.

$\mathrm{CO}_{2}$ selectivity for the photocatalysis alone (UV), plasma SDBD alone and for the coupling processes is presented in figure 10. One can note that when combining the two processes 
carbon dioxide selectivity was improved compared to plasma SDBD alone whatever is the value of SE.

By photocatalysis alone, the selectivity of $\mathrm{CO}_{2}$ was around $59 \%$. When plasma SDBD alone was used the $\mathrm{CO}_{2}$ selectivity is $19 \%$ at $\mathrm{SE}=16 \mathrm{~J} . \mathrm{L}^{-1}$. But by coupling these technologies, the $\mathrm{CO}_{2}$ selectivity is about $40 \%$, an intermediate value between photocatalysis alone and plasma SDBD alone.

Thus,total mineralization by $\mathrm{TiO}_{2}$ photocatalysis is well-known.

\section{Fig 10: Variation of the overall selectivity of $\mathrm{CO}_{2}$ vs. SE using the three}

$$
\operatorname{processes}\left([3 \mathrm{MBA}]=50 \mathrm{mg} \cdot \mathrm{m}^{-3}, \mathrm{Q}=10 \mathrm{~m}^{3} \cdot \mathrm{h}^{-1}, \mathrm{~T}=20{ }^{\circ} \mathrm{C}, \mathrm{RH}=50 \%, \mathrm{I}=20 \mathrm{~W} \cdot \mathrm{m}^{-2}\right) \text {. }
$$

We note that with photocatalysis alone and plasma SDBD/photocatalysis coupling processes, the detectedbyproducts are propionic acid, acetone and acetic acid. We note that with plasma alone, the detected byproducts are acetone and acetic acid.

\subsubsection{On ozone formation}

The residual ozone concentration at the reactor exit for each process (plasma alone and the combined process) is represented in figure 11. The result proves that the amount of ozone formed by plasma SDBDalone is higher to that due to the combined plasma SDBD/TiO $+\mathrm{UV}$. These results suggest that UV can play a role either in inhibiting the ozone formation or in ozone decomposition [38, 40].

Thus, this experiment illustrates that the active species generated $\left({ }^{\circ} \mathrm{O}\right)$ by plasma are able to more oxidize 3MBAand also to react with oxygen molecules for forming ozone [37-40].

Using the study result of Taranto and co-workers [40] the activation of $\mathrm{TiO}_{2}$ by $\mathrm{UV}$ radiation can reduce the formation of ozone or favor its destruction by the following reaction $[9,38$, 40]:

$\mathrm{O}_{3}+\mathrm{e}^{-} \rightarrow 0^{-}+\mathrm{O}_{2}$

or $\mathrm{O}_{3}+\mathrm{hv}(254<\lambda<3500 \mathrm{~nm}) \rightarrow \mathrm{O}_{2}+{ }^{\bullet} \mathrm{O}$

Atomic oxygen thus-formed can play a role in the removal of 3MTBA. This result is in agreement with work of methanol removal [40]. 
We note thatphotocatalyst reactor alone does not produce ozone.

$$
\begin{aligned}
& \text { Figure 11: Variation of amount of ozone with the SE using two processes ([3MBA] }=50 \\
& \left.\qquad \mathrm{mgm}^{-3}, \mathrm{Q}=10 \mathrm{~m}^{3} \cdot \mathrm{h}^{-1}, \mathrm{~T}=20^{\circ} \mathrm{C}, \mathrm{RH}=50 \%, \mathrm{I}=\mathbf{2 0} \mathrm{W} \cdot \mathrm{m}^{-2}\right)
\end{aligned}
$$

In order to more investigate this ozone behavior, the planar reactor was operated in two parts: the first part was with plasma SDBD alone and the second part with photocatalyticprocess $\left(\mathrm{TiO}_{2}+\mathrm{UV}\right)$. The quantification of the ozone was done at the outlet of each part.

The result shows that the amount of ozone was reduced when $\mathrm{TiO}_{2}$ catalyst is irradiated by UV (fig. 12).

At SE equal to $16 \mathrm{~J} . \mathrm{L}^{-1}$, the ozone concentration in the first part is $61 \mathrm{ppmv}$ and decreases to $48 \mathrm{ppmv}$ at the exit of the reactor (the second part). The same behavior is seen with SE equal to $9 \mathrm{~J} . \mathrm{L}^{-1}$. These results show that UV irradiation is able to promote ozone elimination. Ozone can also contribute to 3MBA removal on the photocatalytic surface [40].

This behavior is another reason to explain the synergetic effect between plasma SDBD and photocatalysis.

\section{Figure 12: Variation of amount of ozone with the SE using two parts of planar $\operatorname{reactor}\left([3 \mathrm{MBA}]=50 \mathrm{mg} \cdot \mathrm{m}^{-3}, \mathrm{Q}=10 \mathrm{~m}^{3} \cdot \mathrm{h}^{-1}, \mathrm{~T}=20{ }^{\circ} \mathrm{C}, \mathrm{RH}=50 \%, \mathrm{I}=20 \mathrm{~W} \cdot \mathrm{m}^{-2}\right)$.}

\section{Conclusions}

The goal of this paper was to compare the behavior of $3 \mathrm{MBA}$ removal when catalysis $\left(\mathrm{TiO}_{2}\right.$ without external UV) and plasma SDBD are combined, to each process taken separately in order to determine whether or not a synergy effect was present. Our result showed that the UV light from the SDBD reactor was very weak to activate the $\mathrm{TiO}_{2}$. Its contribution to the removal of 3MBA in plasma SDBD/photocatalysis combination reactor could be ignored.

For each operating parameter, we had unambiguously shown that a synergetic effect for the 3MBAand TMA removal can be observed when NTP is coupled with $\mathrm{TiO}_{2}$ catalyst irradiated by external UV.

The behavior of combining plasma SDBD and photocatalyst in the same planar reactor had shown thatthe ozone can be easily decomposed. 
410 Acknowledgment

411

412 The authors gratefully acknowledge the financial support provided by the French National

413 Research Agency (ANR) for this research work. They thank also the Ahlstrom Company

414 which provided them with the photocatalytic material.

415

416

417

418

419

420

421

422

423

424

425

426

427

428

429

430

431

432 References: 
[1] ADEME, Pollutions olfactives : origine, législation, analyse, traitement. Ademe, Dunod, Angers, 2005.

[2] CITEPA, Emissions dans l'air en France métropole-substance relative à l'acidification, l'eutrophisation et à la pollution photochimique 2011.

[3] H. Huang, D. Y.C. Leung, L.G. Li, K.H. Michael, X. Fu, Photocatalytic destruction of air pollutants with vacuum ultraviolet (VUV) irradiation, Catalysis Today 175 (2011) 310-315.

[4] R. Atkinson, D. L. Baulch, R. A. Cox, J. N. Crowley, R. F. Hampson, R. G. Hynes, M. E. Jenkin, M. J. Rossi, J.Troe, Evaluated kinetic and photochemical data for atmospheric chemistry: Part 1 - gas phase reactions of Ox, HOx, NOx and Sox species. Atmospheric chemistry and Physics Discussions 3 (2003) 6179-6699.

[5] Le Cloirec P. « COV (composés organiques volatils) » 2004, tech.ing. G1835.

[6] M.Wang, A. Lawal, P. Stephenson, J. Sidders, C. Ramshawa,Post-combustion $\mathrm{CO}_{2}$ capture with chemical absorption: A state-of-the-art review, chemical engineering research and design 89 (2011) 1609-1624.

[7] J. Matos, A. Garcia, J-M. Chovelon, C. Ferronato, Combination of Adsorption on Activated Carbon and Oxidative Photocatalysis on $\mathrm{TiO}_{2}$ for Gaseous Toluene Remediation, the Open Materials Science Journal. 4 (2010) 23-25

[8] J. Palau, J. M. Penya-Roja, C. Gabaldon, F. J. Alvarez-Hornos, V. Martinez-Soria, Effect of pretreatments based on UV photocatalysis and photo-oxidation on toluene biofiltration performance, $\mathrm{J}$ Chem Technol Biotechnol.87 (2011) 65-72.

[9] P. Pichat, J. Disdier, C. Hoang-Van, D. Mas, G. Goutailler, C. Gaysse, Purification/deodorization of indoor air and gaseous effluents by $\mathrm{TiO}_{2}$ photocatalysis, Catalysis Today 63 (2000) 363-369

[10] A. Bouzaza, C. Vallet, A. Laplanche, Photocatalytic degradation of some VOCs in the gas phase using an annular flow reactor: determination of the contribution of mass transfer and chemical reaction steps in the photodégradation process. Journal of Photochemistry and Photobiology A: Chemistry. 177 (2006) 212-217.

[11] J.L. Shie, C. H. Lee, C. S. Chiou, C.T. Chang, C. C. Chang, C.Y. Chang, Photodegradation kinetics of formaldehyde using light sources of UVA, UVC and UVLED in the presence of composed silver titanium oxide photocatalyst, Journal of Hazardous Materials 155 (2008) 164-172.

[12] A. A. Assadi, J. Palau, Bouzaza A., D. Wolbert, a continuous air reactor for photocatalytic degradation of 3-methylbutanal : Effect of different operating parameters and Chemical degradation pathway. Chemical engineering research and design 91 (2013) 1307-1316

[13] A.A. Assadi, A. Bouzaza, D. Wolbert,Photocatalytic oxidation of Trimethylamine and Isovaleraldehyde in an annular reactor: Influence of the Mass Transfer and the relative humidity. Journal of Photochemistry and Photobiology A: Chemistry 236 (2012) 61-69. 
[14] R. Enriquez, B. Beaugiraud, P. Pichat, Mechanistic implications of the effect of $\mathrm{TiO}_{2}$ accessibility in $\mathrm{TiO}_{2}-\mathrm{SiO}_{2}$ coatings upon chlorinated organics photocatalytic removal in water. Water Sci Technol., 49 (2004) 147-152.

[15] A. M. Vandenbroucke, R. Morent, N. De Geyter, Ch. Leys, Non-thermal plasmas for noncatalytic and catalytic VOC abatement, Journal of Hazardous Materials 195 (2011) 30-54.

[16] J. Jolibois, K. Takashima, A. Mizuno, Application of a non-thermal surface plasma discharge in wet condition for gas exhaust treatment: NOx removal, Journal of Electrostatics 70 (2012) 300-308.

[17] Y.S. Mok, D.H. Kim, Treatment of toluene by using adsorption and nonthermal plasma oxidation process Current applied physis, 11(2011) S58-S62.

[18] H.H. Kim, S.M. Oh, A. Ogata, S. Futamura, Decomposition of gas-phase benzene using plasmadriven catalyst (PDC) reactor packed with $\mathrm{Ag} / \mathrm{TiO}_{2}$ catalyst, Appl. Catal. B: Environ.56 (2005) 213220.

[19] Zh. Ye, J. Zhao, H. Y. Huang, F.Ma, R. Zhang, Decomposition of dimethylamine gas with dielectric barrier discharge, Journal of Hazardous Materials 260 (2013) 32-39

[20] J.H. Byeon, J. H. Park, Y.S. Jo, K.Y. Yoon, J. Hwang, Removal of gaseous toluene and submicron aerosol particles using a dielectric barrier discharge reactor. J. Hazard. Mater. 175 (2010) $417-422$.

[21] W. Mista, R. Kacprzyk, Decomposition of toluene using non-thermal plasma reactor at room temperature, Catal. Today 137 (2008) 345-349.

[22] E.L. Reddy, J. Karuppiah, A. Renken, L.K. Minsker, C. Subrahmanyam, Kinetics of the decomposition of hydrogen sulfide in a dielectric barrier discharge reactor, Chem. Eng. Technol. 35 (2012) 2030-2034.

[23] O. Guaitella, F. Thevenet, E. Puzenat, C. Guillard, A. Rousseau, $\mathrm{C}_{2} \mathrm{H}_{2}$ oxidation by plasma/TiO combination: Influence of the porosity, and photocatalytic mechanisms under plasma exposure, Applied Catalysis B: Environmental. 80 (2008) 296-305.

[24] A. Maciuca, C. Batiot-Dupeyrat, J-M. Tatibouët,Synergetic effect by coupling photocatalysis with plasma for low VOCs concentration removal from airApplied Catalysis B: Environmental, 125 (2012)432-438

[25]T. Ochiai, Y. Hayashi, M. Ito, K. Nakata, T. Murakami, Y. Morito, A. Fujishima, An effective method for a separation of smoking area by using novel photocatalysis-plasma synergistic air-cleaner, Chemical Engineering Journal 209 (2012) 313-317.

[26] F. Thevenet, O. Guaitella, E. Puzenat, C. Guillard, A. Rousseau,Influence of water vapour on plasma/photocatalytic oxidation efficiency of acetylene. Applied Catalysis B: Environmental 84 (2008) 813-820. 

Wolbert, Dispositif de traitement de gaz et sa méthode d'assemblage, système et procédé de traitement de gaz. CIAT, ENSCR, CNRS. France (2013) Patent $N^{\circ} 1354353$.

[28] Ahlstrom Patent EP 1069950, 2000. AU 735798 US 09/467, 650; JP 2000-542104.

516

517

518

519

520

521

522

523

524

525

526

527

528

529

530

531

532

533

534

535

536

537

538

539

540

541

542

543

544

545

546

[29] T.C. Manley,Proceedings of the 84th General Meeting, New York, 1943.

[30] H.M. Lee, M.B. Chang, Gas-phase removal of acetaldehyde via packed-bed dielectric barrier discharge reactor, Plasma Chem. Plasma Process. 21(2001) 329-343.

[31] M Redolfi., N. Aggadi, X. Duten, S. Touchard, S. Pasquiers, K. Hassouni, 2009. Oxidation of Acetylene in Atmospheric Pressure Pulsed Corona Discharge Cell Working in the Nanosecond Regime, Plasma Chem Plasma Process 29 (2009) 173-195.

[32] K. Allegraud. Décharge à Barrière Diélectrique de Surface : physique et procédé, thèse Ecole polytechnique de Paris, 2008.

[33] P.F. Biard, A. Bouzaza, D. Wolbert, Photocatalytic degradation of two volatile fatty acids in an annular plug-flow reactor: kinetic modeling and contribution of mass transfer rate. Environ. Sci. Technol. 41 (2007) 2908-2914.

[34] Q. Geng, Q. Guo, X. Yue, 2010. Adsorption and Photocatalytic Degradation Kinetics of Gaseous cyclohexane in an Annular Fluidized Bed Photocatalytic Reactor, Ind. Eng. Chem. Res. 49 (2010) 4644-4465.

[35] F.Ouni, A. Khacef, J. M.Cormier, Syngas Production from Propane Using Atmospheric Nonthermal Plasma Plasma Chem Plasma Process 29 (2009) 119-130.

[36] L. Sivachandiran, F. Thevenet, A. Rousseau, Non-Thermal Plasma Assisted Regeneration of Acetone Adsorbed $\mathrm{TiO}_{2}$ Surface,Plasma Chem Plasma Process 33 (2013) 855-871.

[37]A.S. Besov,A.V. Vorontsov, Acceleration of Acetone Destruction Process under Synergistic Action of Photocatalytic Oxidation and Barrier Discharge, Plasma Chemistry and Plasma Processing27 (2007) 624-634.

[38] S. O.Hay, T. N.Obee, the Augmentation of UV Photocatalytic Oxidation with Trace Quantities of Ozone, 4 (1999) 209-221

[39] S. O. Hay, T.N. Obee, C.Thibaud-Erkey, the deactivation of photocatalytic based air purifiers by ambient siloxanes, Applied Catalysis B: Environmental 99 (2010) 435-441

[40] J. Taranto, D. Frochot, P. Pichat, Combining Cold Plasma and $\mathrm{TiO}_{2}$ Photocatalysis To Purify Gaseous Effluents: A Preliminary Study Using Methanol-Contaminated Air, Ind. Eng. Chem. Res. 46 (2007) 7611-7614. 
547 [41] P. Pichat, Some views about indoor air photocatalytic treatment using $\mathrm{TiO}_{2}$ : Conceptualization of 548 humidity effects, active oxygen species, problem of $\mathrm{C}_{1}-\mathrm{C}_{3}$ carbonyl pollutants, Applied Catalysis $\mathrm{B}$ : 549 Environmental 99 (2010) 428-434.

550 [42] A. Fujishima, X. Zhang, D. A. Tryk, $\mathrm{TiO}_{2}$ photocatalysis and related surface phenomena, Surface 551 Science Reports 63 (2008) 515-582.

552 [43] M. A. Henderson, A surface science perspective on $\mathrm{TiO}_{2}$ photocatalysis, Surface Science Reports $553 \quad 66(2011) 185-297$.

554 [44] P. Pichat, representative examples of infrared spectroscopy uses in semiconductor photocatalysis, 555 Catalysis Today (2013) in press.

556 [45]K. Allegraud, O. Guaitella, A. Rousseau, Spatio-temporal breakdown in surface DBDs: evidence 557 of collective effect, J. Phys. D: Appl. Phys. 40 (2007) 7698-7706.

558 [46] T. N. Obee, S. Satyapal, Photocatalytic decomposition of DMMP on titania, Journal of 559 Photochemistry and Photobiology A: Chemistry 118 (1998) 45-51.

560

561

562

563

564

565

566

567

568

569

570

571

572 
Table 1: Parameters of plasma $\mathrm{SDBD}+\mathrm{TiO}_{2} / \mathrm{UV}$ reactor

575

\begin{tabular}{|c|c|}
\hline Parameter & Value \& domain \\
\hline Gas temperature & Ambient $(293 \mathrm{~K})$ \\
\hline Gas pressure & Atmospheric pressure $(1 \mathrm{~atm})$ \\
\hline Relative humidity & $50 \pm 5 \%$ \\
\hline Applied voltage & 12 to $29 \mathrm{kV}$ \\
\hline Gas flowrate & 4 to $10 \mathrm{Nm}^{3} \mathrm{~h}^{-1}$ \\
\hline Inlet concentration & 50 to $100 \mathrm{mg} \mathrm{m}^{-3}$ \\
\hline UV intensity & $20 \mathrm{~W} \mathrm{~m}^{-2}$ \\
\hline
\end{tabular}

576

Table 2:Analysis conditions for the gas chromatograph

\begin{tabular}{|c|c|c|c|c|}
\hline \multicolumn{3}{|c|}{ Gas pressure } & \multicolumn{2}{c|}{ Zone temperature } \\
\hline $\mathrm{N}_{2}$ (gas carrier, kPa) & $\mathrm{H}_{2}(\mathrm{kPa})$ & Air $(\mathrm{kPa})$ & Injector $\left({ }^{\circ} \mathrm{C}\right)$ & Oven $\left({ }^{\circ} \mathrm{C}\right)$ \\
\hline 105 & 40 & 100 & 110 & 50 \\
\hline
\end{tabular}

578

579

580

581

582

583

584

585

586

587 
Figures:

589

590

591

592

593

594

595

596

597

598

599

600

601

602

603

604

605

606

607

608

609

610

611

612

613

614

615

616

617

618

619

620

621

622

623

Figure 1: Schema (b) and sectional drawing (a) of plasma SDBD coupled with photocatalysis in planar reactor.

Figure 2: (a) General scheme for coupling plasma SDBD and photocatalysis, (b) photographs of plasma SDBD in planar reactor.

Figure 3: Schematic view of the experimental setup

Figure 4: Lissajous curve obtained at $50 \mathrm{~Hz}$.

Figure 5: Dependence of RE on SE on in situ in different plasma systems without external UV $\left([3 \mathrm{MBA}]=50 \mathrm{mg} \mathrm{m}^{-3}, \mathrm{Q}=10 \mathrm{~m}^{3} \mathrm{~h}^{-1}, \mathrm{~T}=20^{\circ} \mathrm{C}, \mathrm{RH}=50 \%\right)$.

Figure 6.a: Variation of $\mathrm{CO}$ and $\mathrm{CO}_{2}$ selectivities vs. the SE using two processes without external UV: empty symbol = selectivity of $\mathrm{CO}_{2}$ and full symbol = selectivity of $\mathrm{CO}$ $\left([3 \mathrm{MBA}]=50 \mathrm{mg} \mathrm{m}^{-3}, \mathrm{Q}=10 \mathrm{~m}^{3} \mathrm{~h}^{-1}, \mathrm{~T}=20^{\circ} \mathrm{C}, \mathrm{RH}=50 \%\right)$.

Figure 6.b. Variation of mass balances and byproducts of 3MBA with residence time using two processes without external UV ([3MBA] $=50 \mathrm{mg} \mathrm{m}^{-3}, \mathrm{Q}=10 \mathrm{~m}^{3} \mathrm{~h}^{-1}, \mathrm{~T}=20{ }^{\circ} \mathrm{C}, \mathrm{RH}=$ $50 \%)$.

Figure 7: Dependence of the ozone formation on SE in situ under different plasma systems without external UV ([3MBA] $\left.=50 \mathrm{mg} \mathrm{m}^{-3}, \mathrm{Q}=10 \mathrm{~m}^{3} \mathrm{~h}^{-1}, \mathrm{~T}=20^{\circ} \mathrm{C}, \mathrm{RH}=50 \%\right)$

Figure.8: 3MBAremoval efficiency by coupling process vs the sum of removal efficiency of plasma and photocatalysis at different residence time, inlet concentration and specific energy in planar reactor $\left(\mathrm{T}=20^{\circ} \mathrm{C}, \mathrm{RH}=50 \%, \mathrm{I}=20 \mathrm{~W} \cdot \mathrm{m}^{-2}\right)$.

Figure 9: Trimethylamine conversion with flow rate for the different tested configurations $\left(\mathrm{SE}=13 \mathrm{~J} . \mathrm{L}^{-1},[\mathrm{TMA}]=145 \mathrm{mg} / \mathrm{m}^{3}, \mathrm{RH}=50 \%, \mathrm{~T}=20^{\circ} \mathrm{C}\right)$.

Figure 10: Variation of the overall selectivity of $\mathrm{CO}_{2}$ vs. SE using the three processes $\left([3 \mathrm{MBA}]=50 \mathrm{mg} \cdot \mathrm{m}^{-3}, \mathrm{Q}=10 \mathrm{~m}^{3} \cdot \mathrm{h}^{-1}, \mathrm{~T}=20^{\circ} \mathrm{C}, \mathrm{RH}=50 \%, \mathrm{I}=20 \mathrm{~W} \cdot \mathrm{m}^{-2}\right.$ ).

Figure 11: Variation of amount of ozone with the SE using two processes ([3MBA] $=50 \mathrm{mg}$ $\left.\mathrm{m}^{-3}, \mathrm{Q}=10 \mathrm{~m}^{3} \cdot \mathrm{h}^{-1}, \mathrm{~T}=20{ }^{\circ} \mathrm{C}, \mathrm{RH}=50 \%, \mathrm{I}=20 \mathrm{~W} \cdot \mathrm{m}^{-2}\right)$.

Figure 12: Variation of amount of ozone with the SE at exits of plasma alone and combined process in planar reactor $\left([3 \mathrm{MBA}]=50 \mathrm{mg} \cdot \mathrm{m}^{-3}, \mathrm{Q}=10 \mathrm{~m}^{3} \cdot \mathrm{h}^{-1}, \mathrm{~T}=20{ }^{\circ} \mathrm{C}, \mathrm{RH}=50 \%, \mathrm{I}=20\right.$ $\left.\mathrm{W} \cdot \mathrm{m}^{-2}\right)$. 


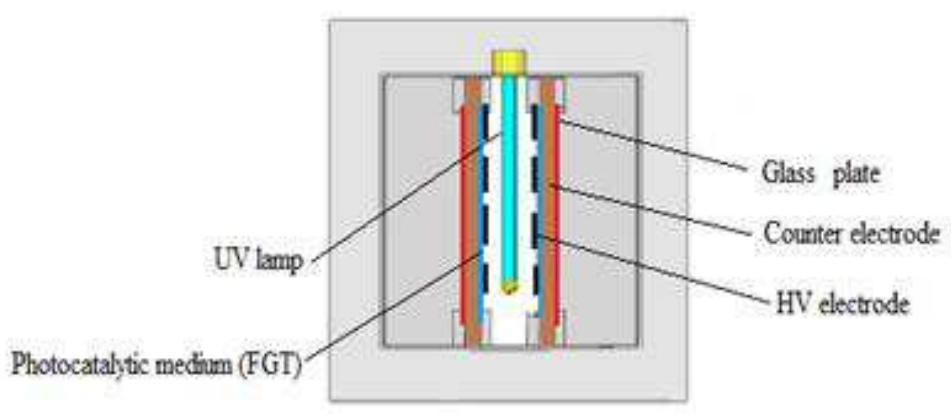

(a)

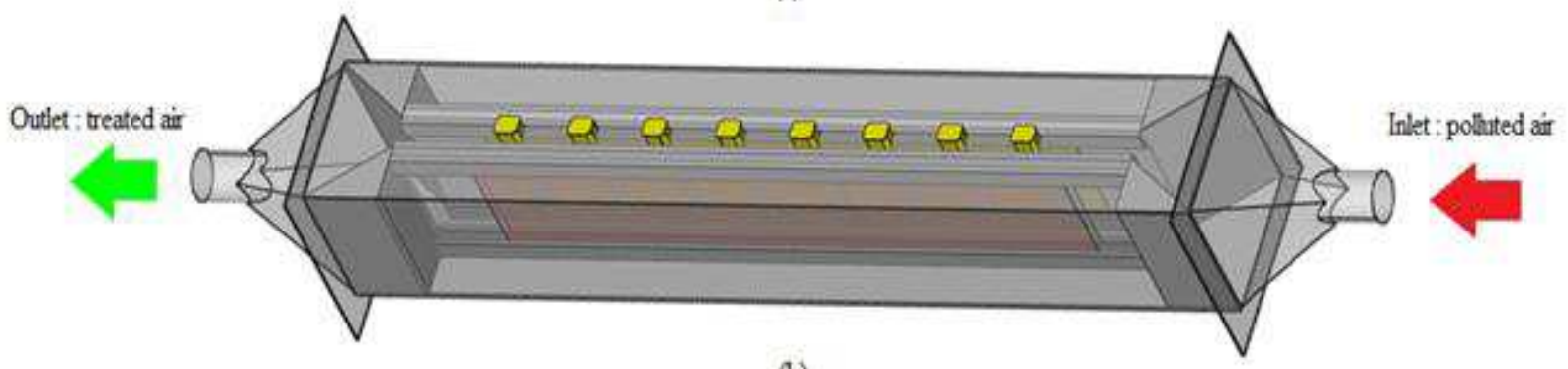

(b)

627

628

629

630

631

632

633

634

635

636

637

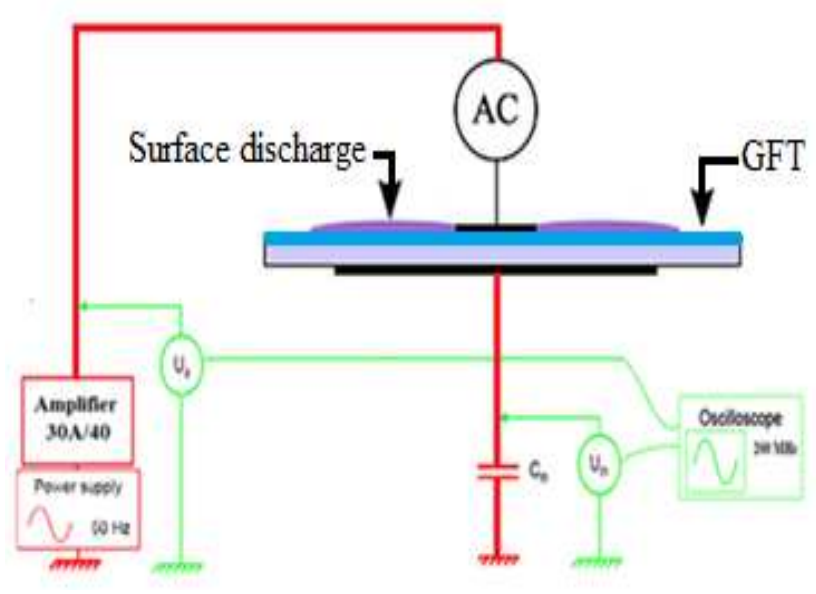

(a)

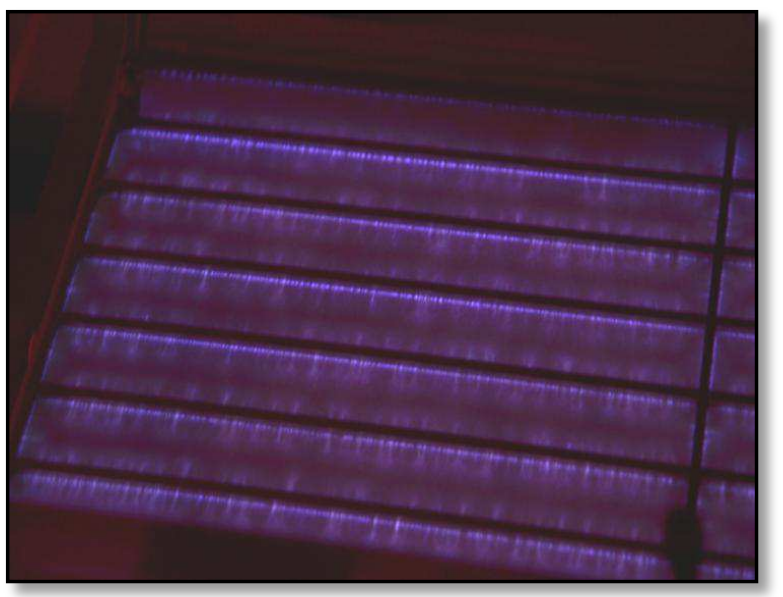

(b)

Figure 2: (a) General scheme for coupling non-thermal plasma and photocatalysis, (b) photographs of plasma SDBD in planar reactor. 


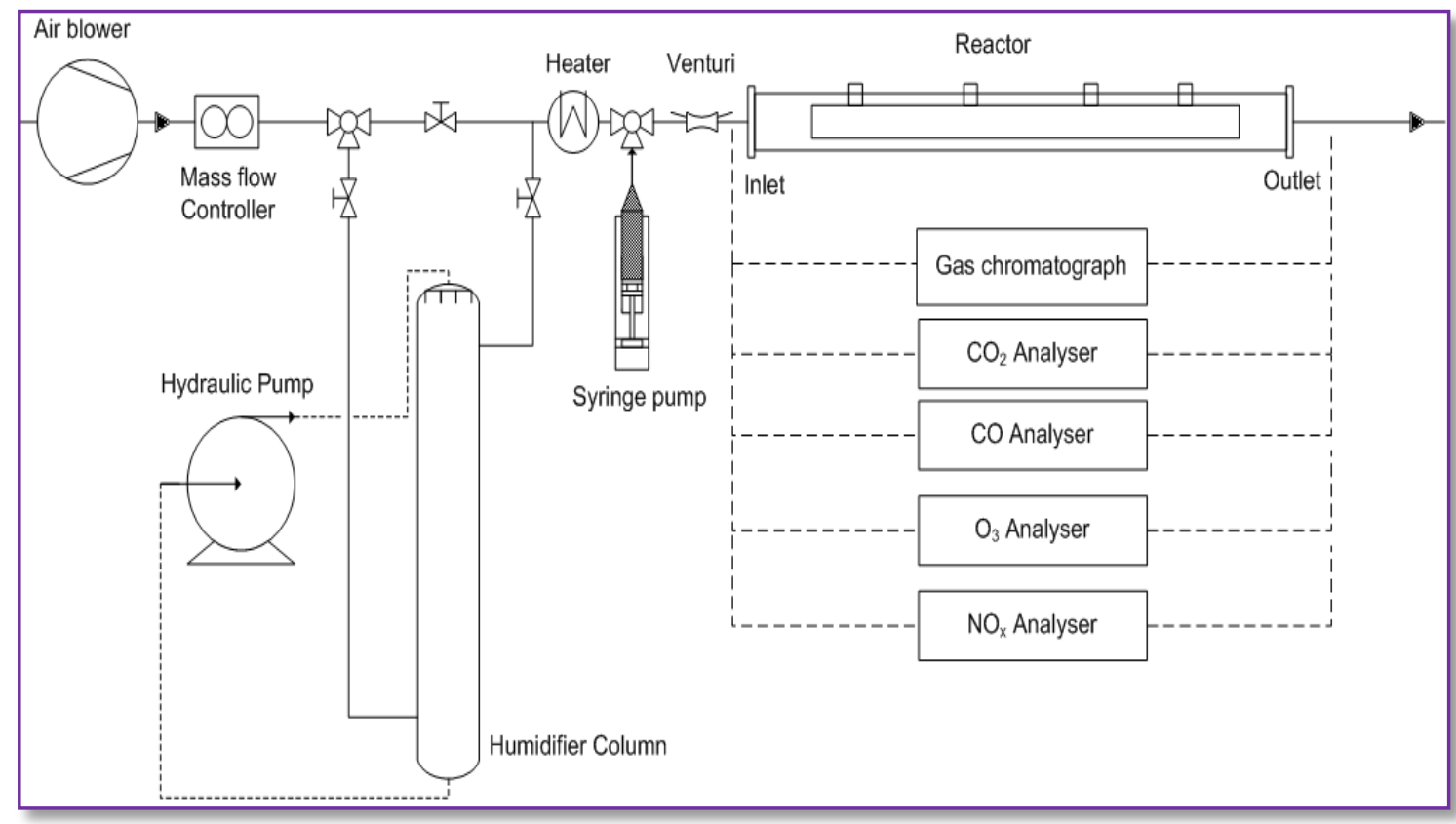

Figure 3: Schematic view of the experimental setup

640

641

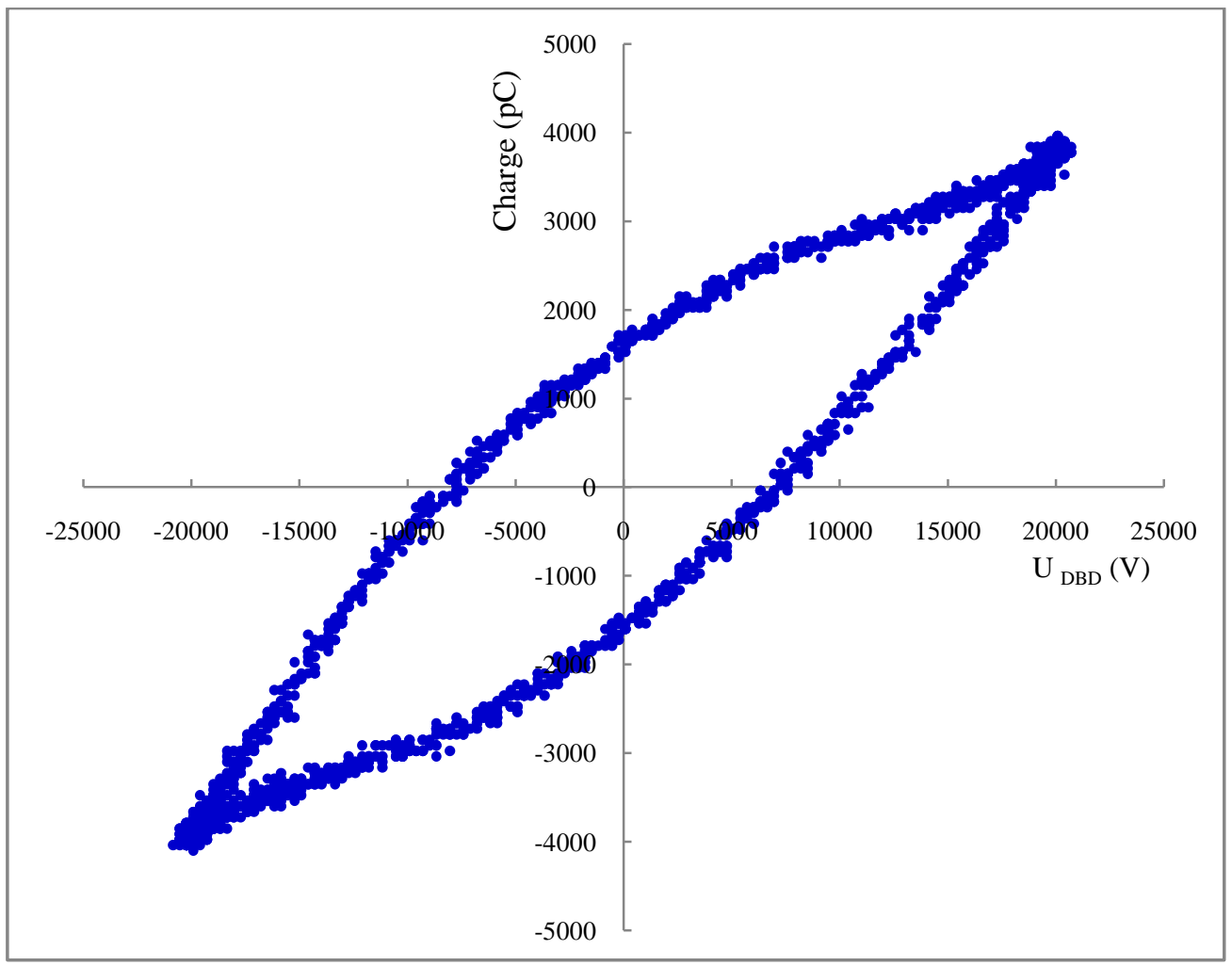

Figure 4: Lissajous curve obtained at $50 \mathrm{~Hz}$. 


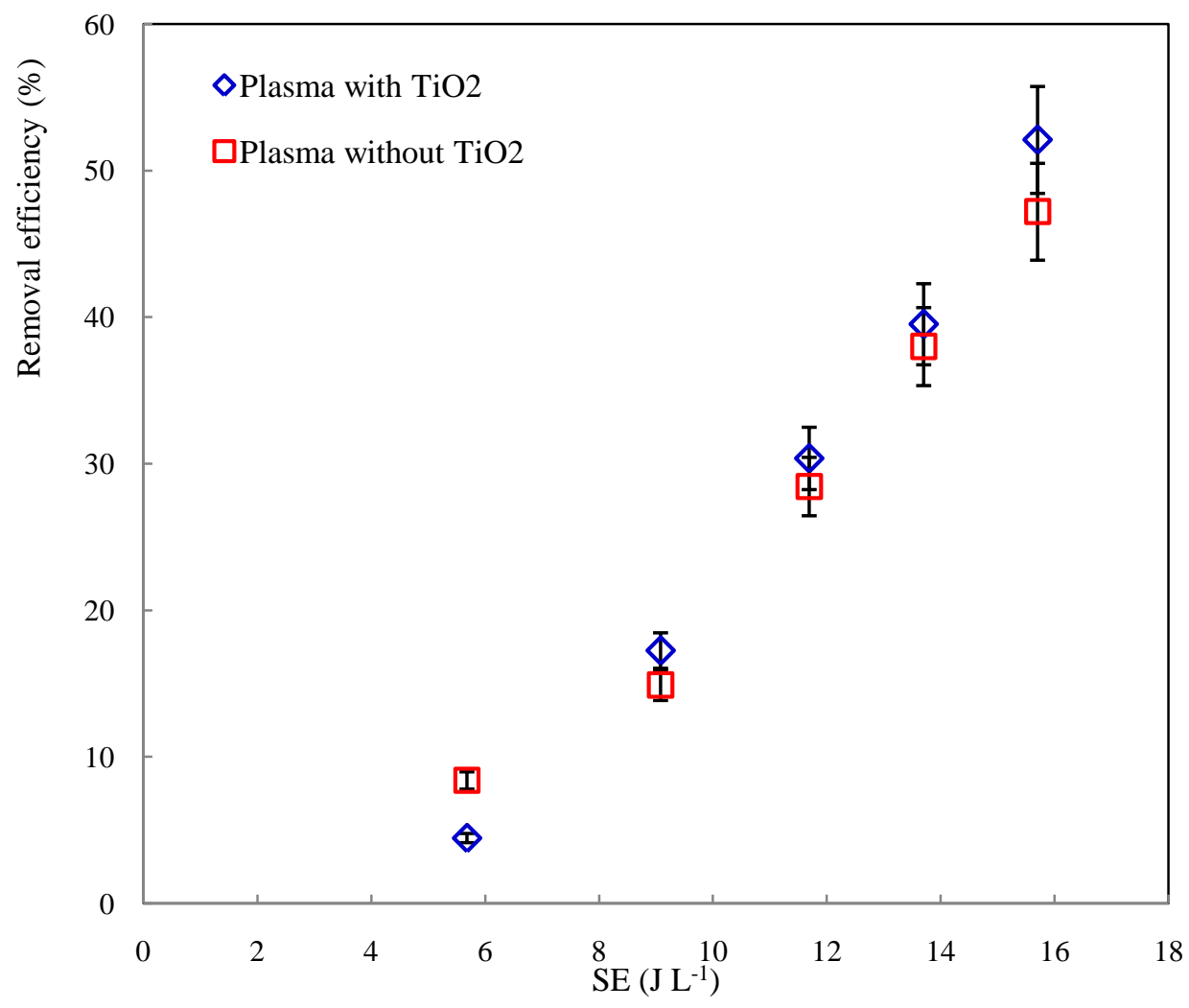

646 Figure 5: Dependence of RE on SE in situ in different plasma systems without external UV 647 $\left([3 \mathrm{MBA}]=50 \mathrm{mg} \mathrm{m}^{-3}, \mathrm{Q}=10 \mathrm{~m}^{3} \mathrm{~h}^{-1}, \mathrm{~T}=20{ }^{\circ} \mathrm{C}, \mathrm{RH}=50 \%\right)$.

648

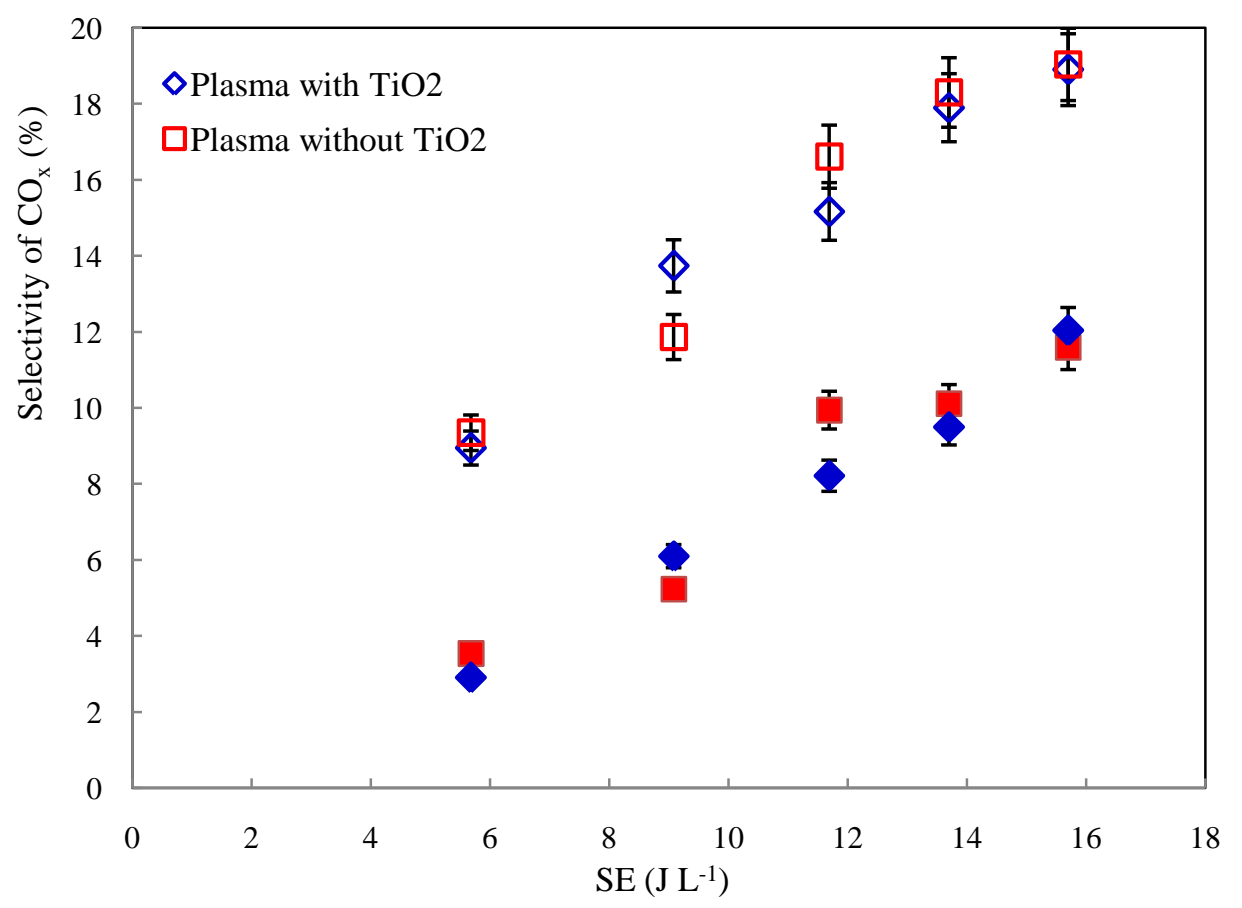

Figure 6.a: Variation of $\mathrm{CO}$ and $\mathrm{CO}_{2}$ selectivities vs. the specific energy using two processes without external UV: empty symbol = selectivity of $\mathrm{CO}_{2}$ and full symbol $=$ 652 selectivity of $\mathrm{CO}\left([3 \mathrm{MBA}]=50 \mathrm{mg} \mathrm{m}^{-3}, \mathrm{Q}=10 \mathrm{~m}^{3} \mathrm{~h}^{-1}, \mathrm{~T}=20{ }^{\circ} \mathrm{C}, \mathrm{RH}=50 \%\right)$. 


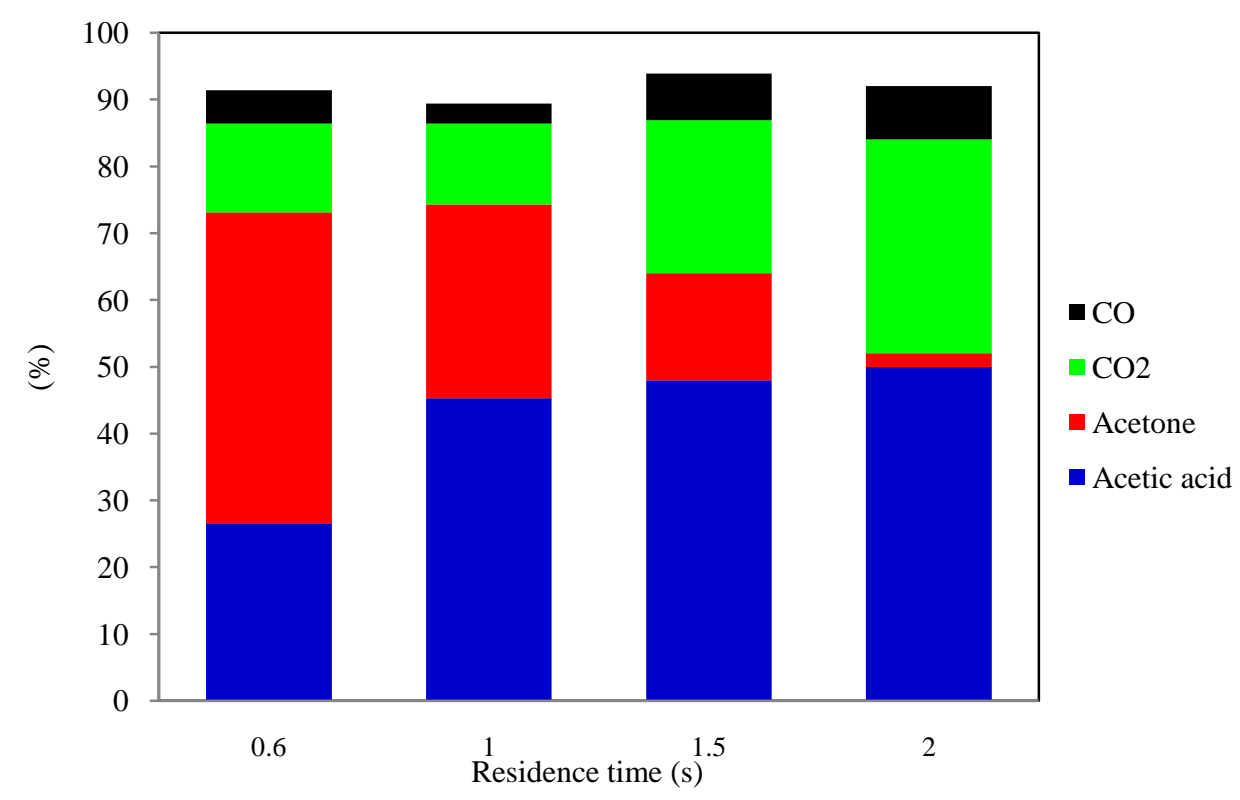

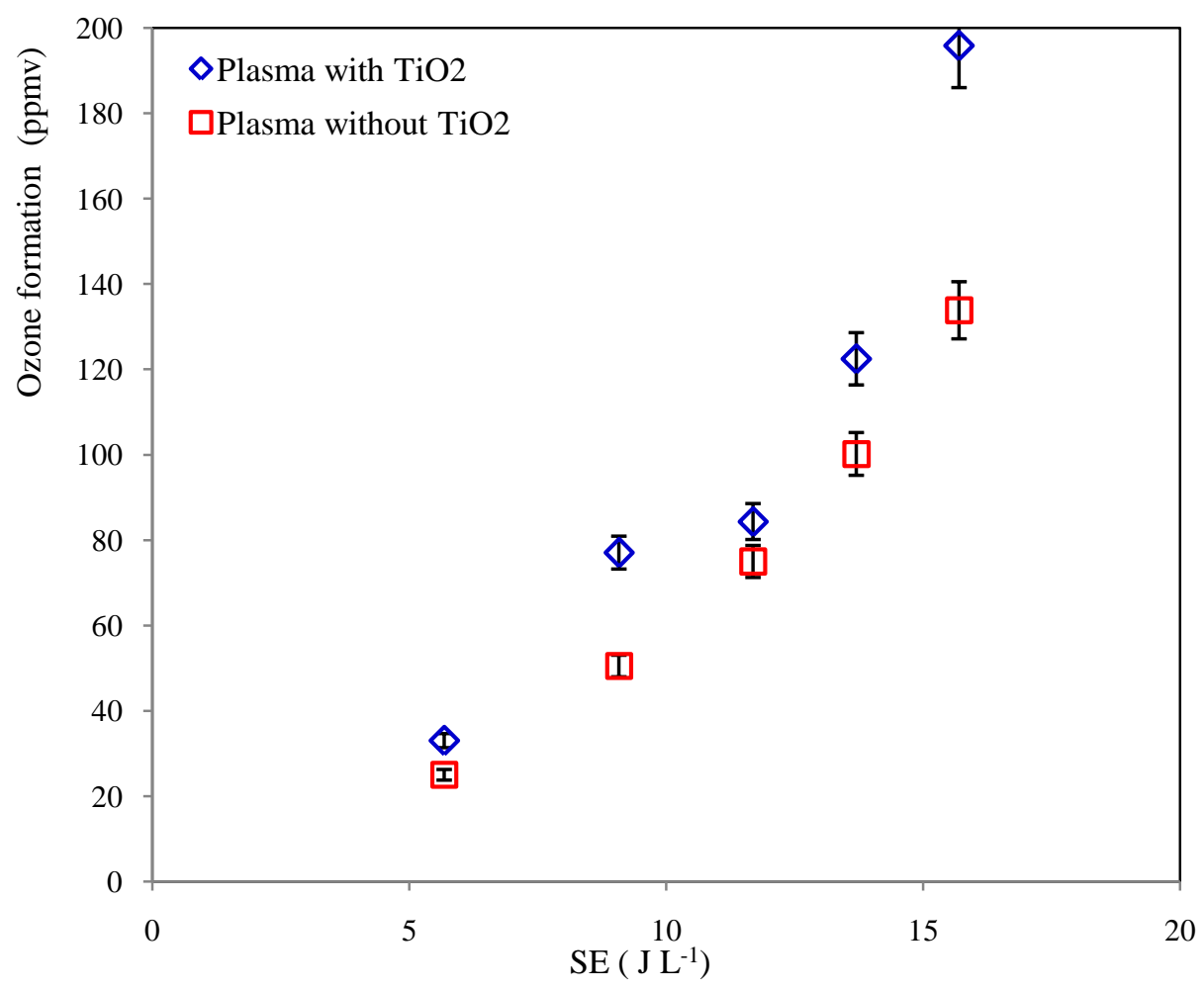

Figure.6.b. Variation of mass balances and by-products of $3 \mathrm{MBA}$ with residence time using two processes without external UV $\left([3 \mathrm{MBA}]=50 \mathrm{mg} \mathrm{m}^{-3}, \mathrm{Q}=10 \mathrm{~m}^{3} \mathrm{~h}^{-1}, \mathrm{~T}=20^{\circ} \mathrm{C}, \mathrm{RH}=\right.$ $50 \%)$. 


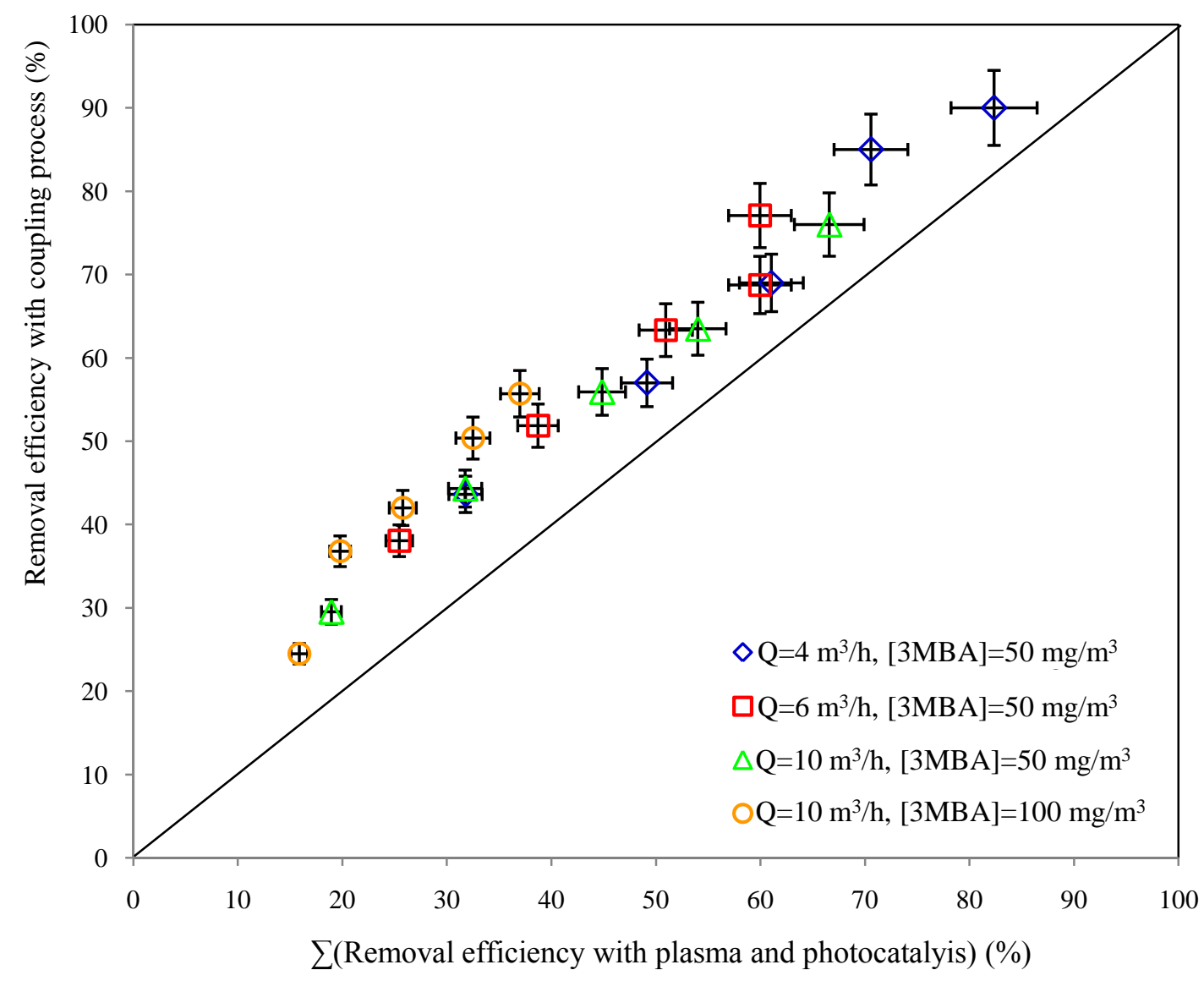

662

Figure.8: 3MBA removal efficiency by coupling process vs the sum of removal efficiency of 664 plasma and photocatalysis at different residence time, inlet concentration and specific energy 665 in planar reactor $\left(\mathrm{T}=20^{\circ} \mathrm{C}, \mathrm{RH}=50 \%, \mathrm{I}=20 \mathrm{~W} \cdot \mathrm{m}^{-2}\right)$. 


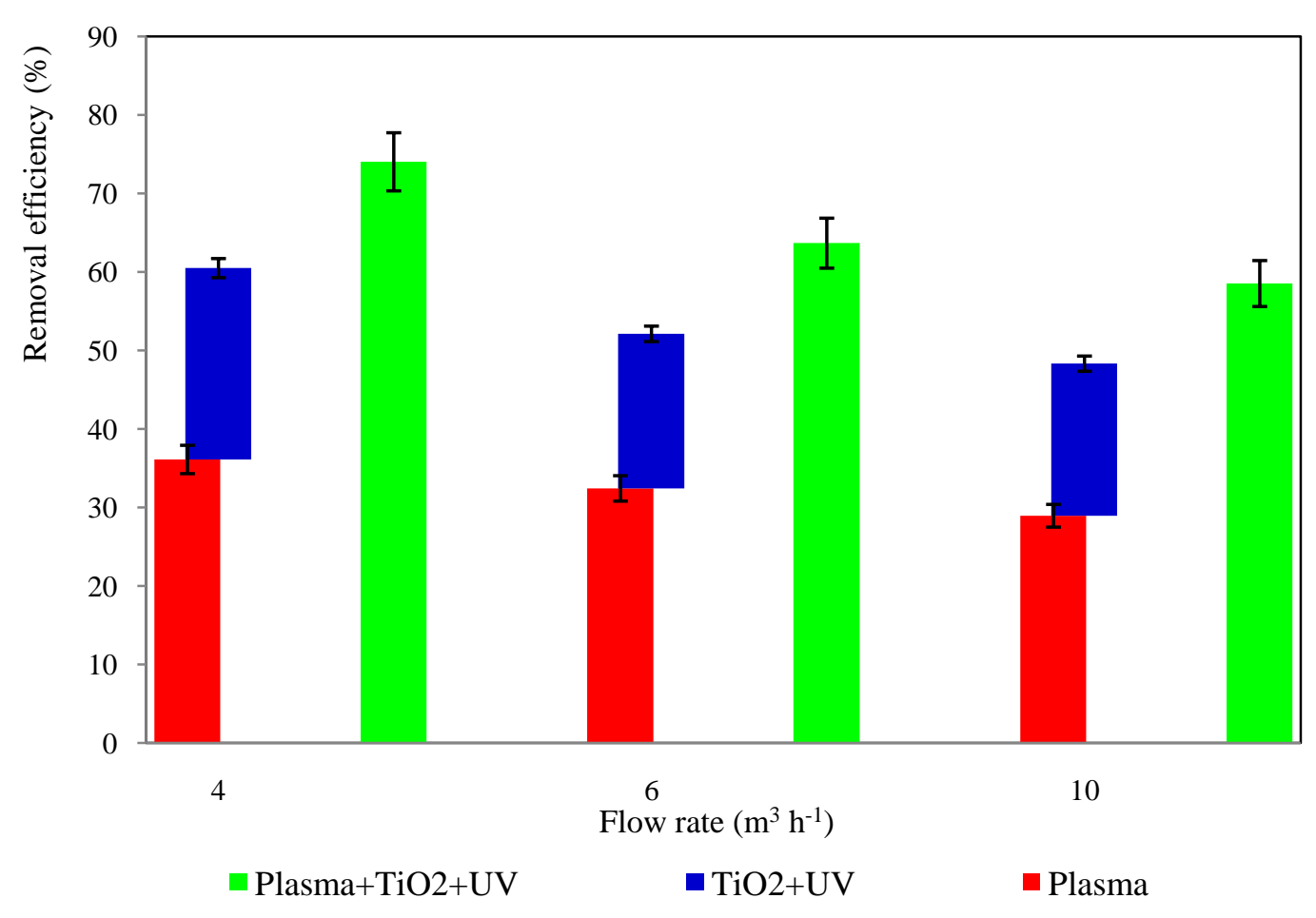

Figure 9: Trimethylamine conversion with flow rate for the different tested configurations 669 $\left(\mathrm{SE}=13 \mathrm{~J} . \mathrm{L}^{-1},[\mathrm{TMA}]=145 \mathrm{mg} / \mathrm{m}^{3}, \mathrm{RH}=50 \%, \mathrm{~T}=20{ }^{\circ} \mathrm{C}\right)$.

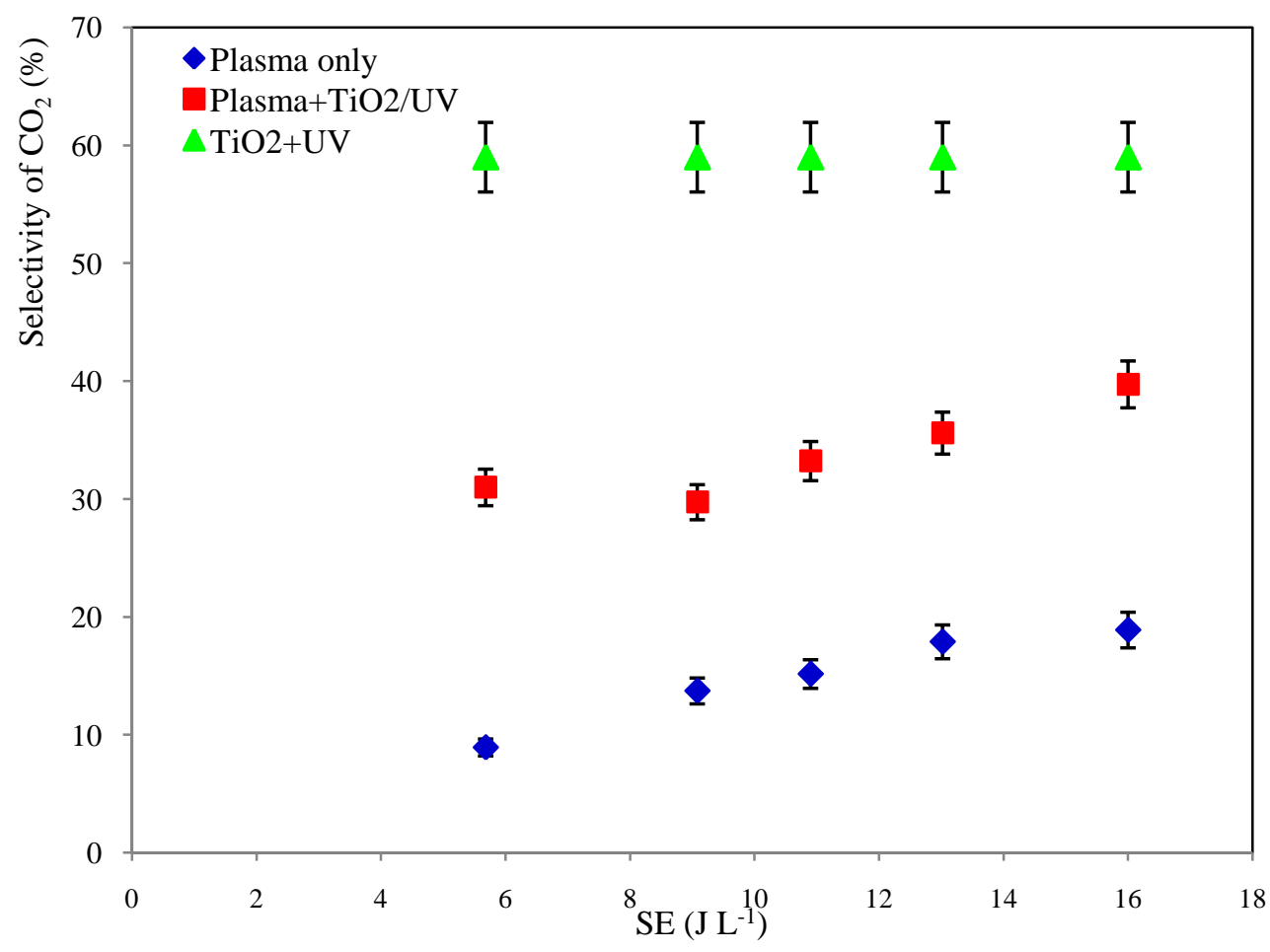

$$
\left([3 \mathrm{MBA}]=50 \mathrm{mg} \cdot \mathrm{m}^{-3}, \mathrm{Q}=10 \mathrm{~m}^{3} \cdot \mathrm{h}^{-1}, \mathrm{~T}=20^{\circ} \mathrm{C}, \mathrm{RH}=50 \%, \mathrm{I}=20 \mathrm{~W} \cdot \mathrm{m}^{-2}\right) \text {. }
$$




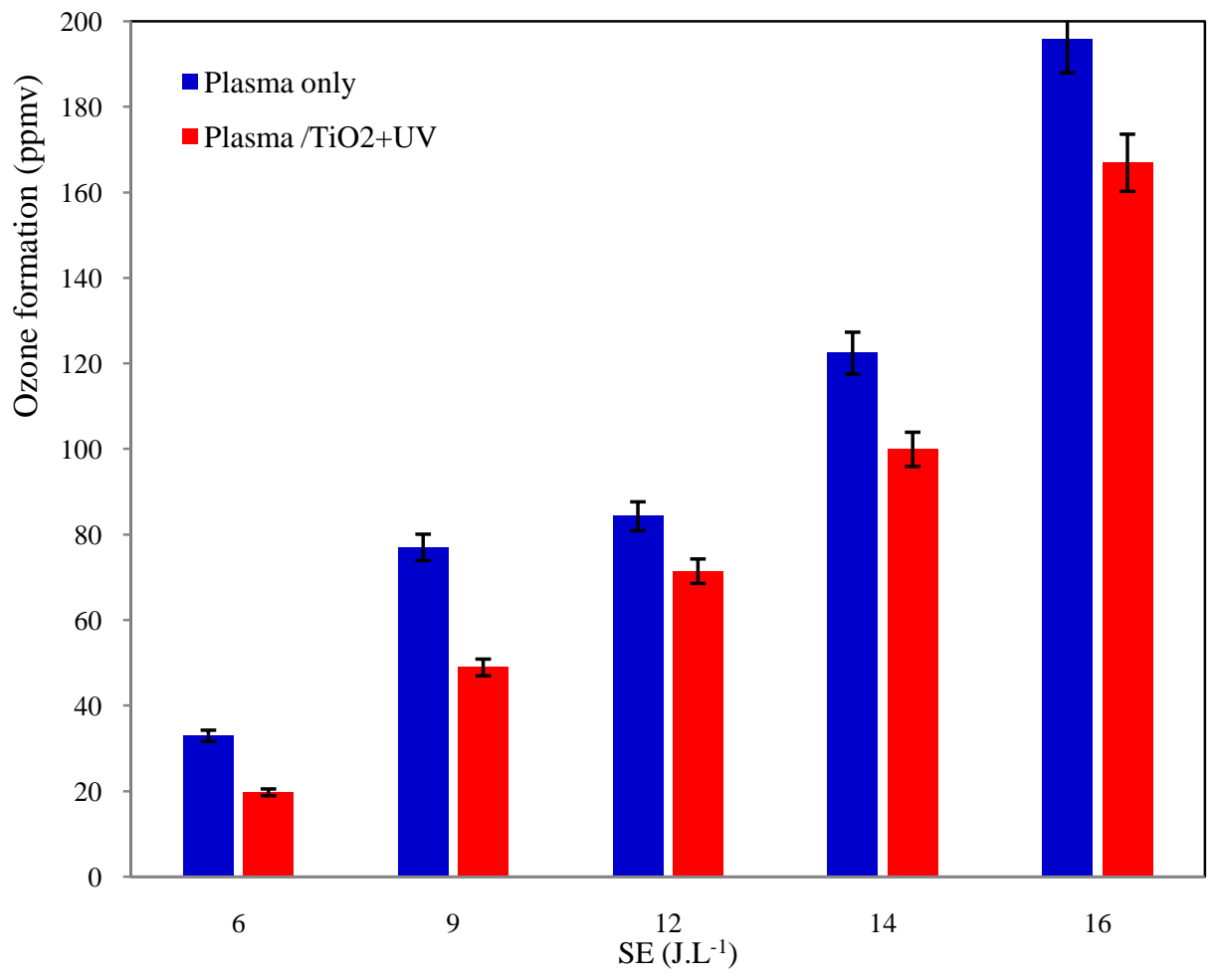

673

674 675

Figure 11: Variation of amount of ozone with the SE using two processes ([3MBA] $=50 \mathrm{mg}$ $\left.\mathrm{m}^{-3}, \mathrm{Q}=10 \mathrm{~m}^{3} \cdot \mathrm{h}^{-1}, \mathrm{~T}=20{ }^{\circ} \mathrm{C}, \mathrm{RH}=50 \%, \mathrm{I}=20 \mathrm{~W} \cdot \mathrm{m}^{-2}\right)$.

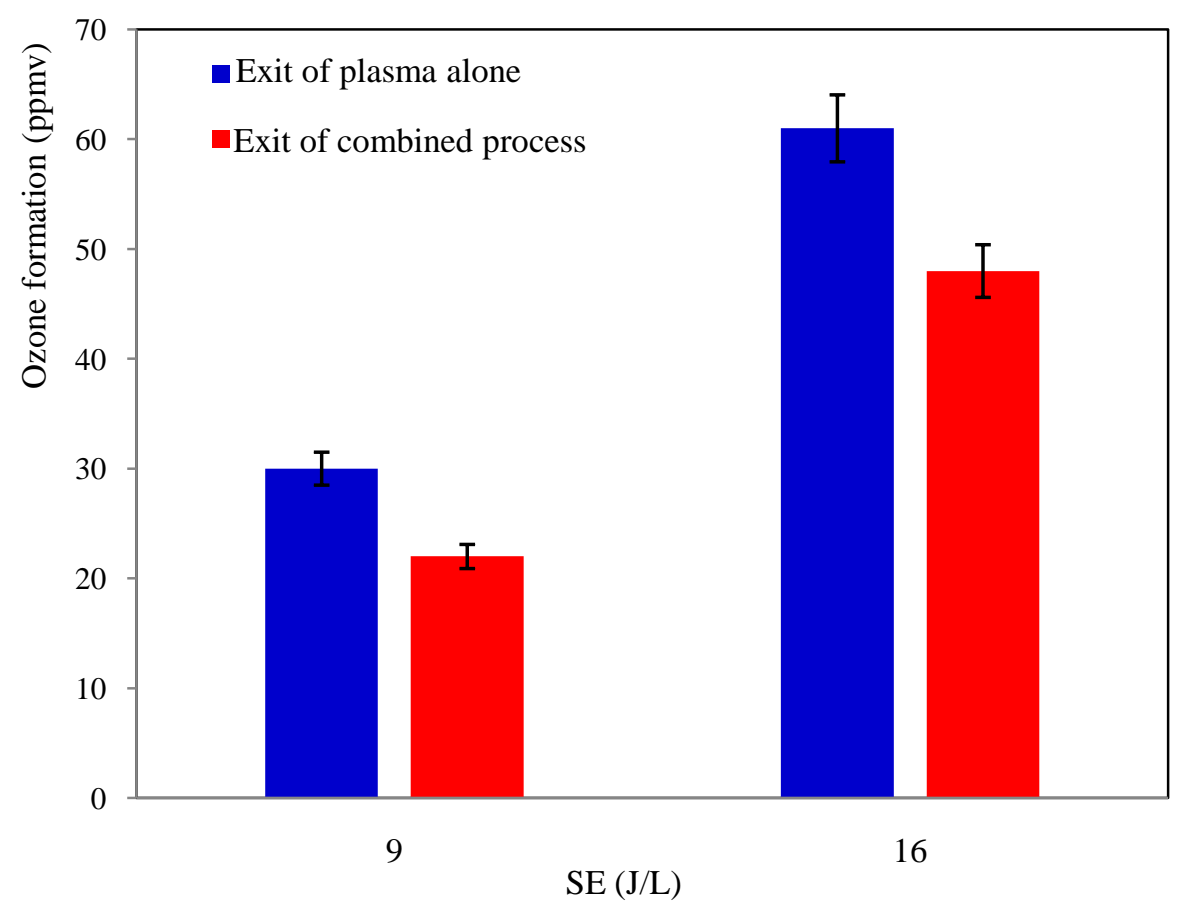

Figure 12: Variation of amount of ozone with the SE at exits of plasma alone and combined processin planar reactor $\left([3 \mathrm{MBA}]=50 \mathrm{mg} \cdot \mathrm{m}^{-3}, \mathrm{Q}=10 \mathrm{~m}^{3} \cdot \mathrm{h}^{-1}, \mathrm{~T}=20^{\circ} \mathrm{C}, \mathrm{RH}=50 \%, \mathrm{I}=20\right.$ 